\title{
KINETIC ASPECTS OF NITRATE REDUCTION ${ }^{1}$ )
}

\author{
L. H. J. BONGERS \\ T.N.O. Solar Energy Project, Laboratory for Plant Physiological Research, \\ Agricultural University, Wageningen, Holland ${ }^{2}$ )
}

\begin{abstract}
SUMMARY
Kinetic studies were made of the photochemical reduction of nitrate and nitrite to ammonia and correlations to the photosynthetic $\mathrm{CO}_{2}$ assimilation investigated. Two molecules of $\mathrm{O}_{2}$ are evolved per molecule of nitrate reduced to ammonia and $1 \frac{1 / 2}{2}$ molecules of $\mathrm{O}_{2}$ per molecule of nitrite.

In the rate-limiting light intensity region, the rate of oxygen production was found to be independent of the nature of the oxidant $\left(\mathrm{CO}_{2}, \mathrm{NO}_{3}{ }^{-}\right.$or $\left.\mathrm{NO}_{2}^{-}\right)$; the quantum yield of nitrate reduction is equal to that of $\mathrm{CO}_{2}$ reduction. Hence the energetic efficiency of nitrate and nitrite reduction is only about $1 / 3$ of the efficiency of the $\mathrm{CO}_{2}$ assimilation.

Under light saturation the rate of oxygen evolution in $\mathrm{CO}_{2}$ containing media is not increased by a simultaneously occurring $\mathrm{NO}_{3}^{-}$and $\mathrm{NO}_{2}^{-}$reduction.
\end{abstract}

\section{INTRODUCTION}

In a previous article (1) we described nitrogen assimilation by cultures of green algae under various conditions. It was found that there was no conversion of inorganic nitrogen into cell nitrogen in the absence of simultaneous $\mathrm{CO}_{2}$-assimilation, unless the $\mathrm{N} / \mathrm{C}$ ratio of the algae had been disturbed during pretreatment. We found, however, that normal cells grown in a complete nutrient medium (and having a nitrogen content of $8 \%$ to $10 \%$ on a dry weight basis) if exposed to light in the absence of $\mathrm{CO}_{2}$, excrete into the surrounding liquid an amount of ammonia which corresponds to the amount of nitrate disappearing from the nitrate-containing medium.

We considered this excretion as being due to the absence of suitable carbon skeletons which function as ammonia acceptors under normal conditions of growth. Furthermore, we tried to correlate the rate of $\mathrm{CO}_{2}$-reduction (in the presence of $\mathrm{CO}_{2}$ ) to the rate of ammonia excretion (in the absence of $\mathrm{CO}_{2}$ ), both as a function of light intensity.

The conversion of nitrate into ammonia is accompanied by the production of oxygen. In the present paper, experiments are described in which the rate of $\mathrm{NH}_{4}+$-formation is estimated by measuring the oxygen evolution. The amount of oxygen evolved per unit of nitrate reduced or ammonia excreted is indicated by the $\mathrm{O}_{2} / \mathrm{N}$ ratio. The respective reduction rates of $\mathrm{CO}_{2}$ and nitrate could therefore both be followed by means of identical procedures (manometry) which allowed accurate measurements of the relative rates in weak intensities as well. Direct ammonium estimates during brief experiments in weak light are hardly feasible.

In the same way, the correlation between the rates of nitrate and $\mathrm{CO}_{2}$ reduction is measured as a function of light intensity. Furthermore, some experiments are described which are concerned with the question as to how far the rate of oxygen output in strong "saturating" light depends upon the availability of both types of oxidants.

1) Received for publication November 19, 1957.

2) Communication no. 169 of this laboratory; 59th Communication on Photosynthesis. 


\section{EXPERIMENTAL METHODS}

The algal material used, Scenedesmus sp., was cultivated in a modified continuous culture device (cf. Myers and Clank (2). It was made of three concentric glass tubes surrounding a fluorescent tube (daylight, $30 \mathrm{~W}$ nominal rating). In the inner annulus between growth chamber and lamp constant temperature water was circulated. This apparatus is shown in Fig. 1. Sedimentation of the cells was prevented by continuous aeration with a stream of $5 \% \mathrm{CO}_{2}$ in the air.

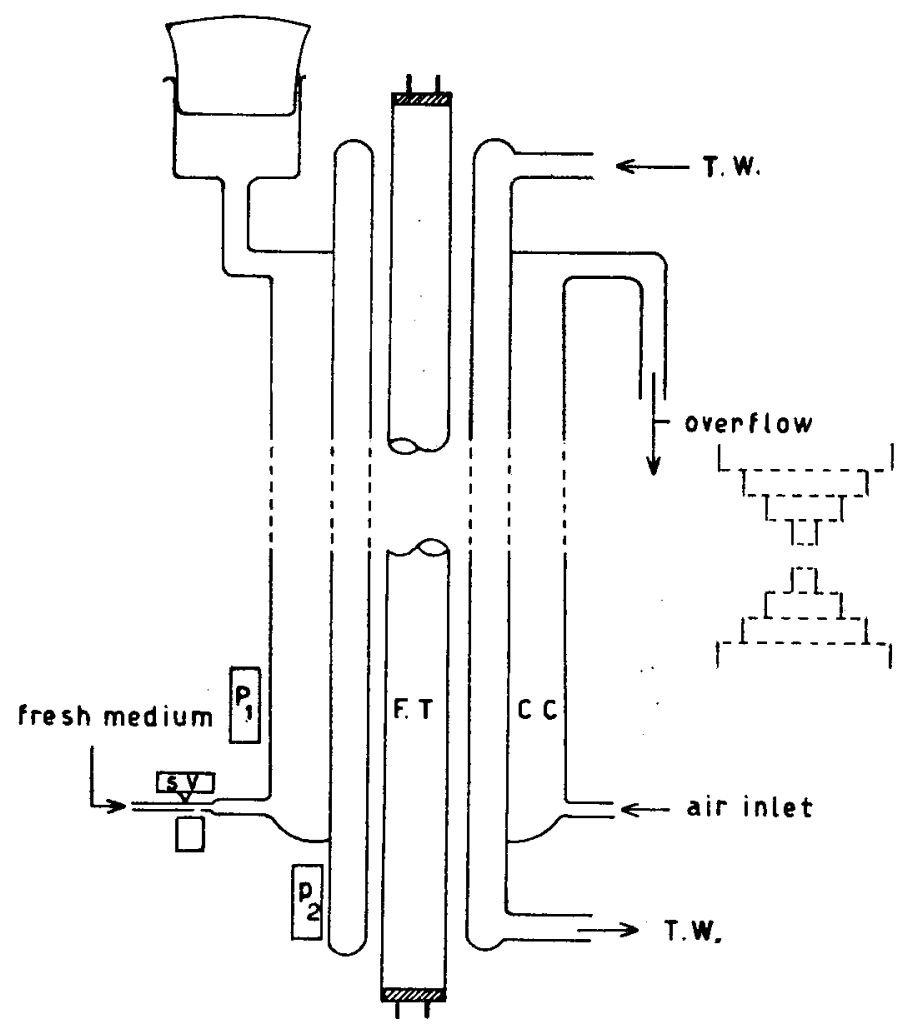

Fig. 1 Schematic drawing of the culture arrangement. C.C. : culture chamber ; volume $750 \mathrm{ml}$; thickness culture chamber $7 \mathrm{~mm}$; F.T. : fluorescent tube, 30 Watts, daylight; T.W.: inlet and outlet of water of constant temperature; $\mathrm{P}_{1}$ and $\mathrm{P}_{2}$ : photocells; S.V.: solenoid valve.

The density of the culture during growth was kept constant by adequate dilution with fresh nutrient solution. The supply of fresh medium was automatic and controlled, via a solenoid valve, by a system of two photo cells. One of these was exposed directly to the light source via an adjustable wire screen and the other illuminated via the algal suspension. The valve was operated by a difference between the two photocurrents. The culture density could be varied by using wire screens of different transmission.

Alternate dark and light periods were given to the algae in such a way that a complete life cycle (in accordance with observations of TAMIYA et al. (3) was obtained in 24 hours at the temperature and light intensity prevailing. 
At $30^{\circ} \mathrm{C}$ and at the end of a light period of 16 hours the culture consisted of a fairly homogeneous suspension of mature "light" cells which were about to divide. In the subsequent dark period the cells normally divided into 8 or 4 daughter cells. The $\mathrm{pH}$ of the KNOP culture solution was maintained at about 7.0.

For most experiments vigorously growing cells were used, harvested about 5 hours after the beginning of the light period.

Measurements of photosynthetic oxygen evolution were made with the manometric method in a 0.2 molar carbonate buffer at $\mathrm{pH}$ 8.4. This $\mathrm{pH}$ is somewhat lower than that normally used, but it was found that the oxygen production was not materially different from the rate observed in a buffer of $\mathrm{pH}$ 8.7. This relatively low $\mathrm{pH}$ was used in order to obtain comparable conditions during measurements of the reduction of either carbon dioxide, nitrate or nitrite. In the absence of $\mathrm{CO}_{2}$, the latter two substrates are photochemically reduced to ammonia at $\mathrm{pH}$ values of between 7.5 and 9.0 (cf. (1), but at higher $\mathrm{pH}$ values toxic effects of $\mathrm{NH}_{3}$ may interfere. In our brief experiments no such concentration of ammonia accumulated to influence the observed rates at $\mathrm{pH} 8.4$.

Nitrate and nitrite reduction were determined by manometric measurements of the oxygen evolution of algae suspended in a solution of a $1 / 15 \mathrm{M}$ tris (hydroxymethyl) amine-methane-phosphate buffer, or by estimating the amount of ammonia excreted. After centrifuging the cells the ammonia concentration built up in the suspension medium during illumination was determined in the supernatant by means of the Nessler technique (cf. SNell and Snell (4). Light absorption was measured at $410 \mathrm{~m} \mu$.

In our manometric experiments we used flat cylindrical vessels (bottom area $\sim 27 \mathrm{~cm}^{2}$, volume $\sim 27 \mathrm{ml}$ ) each provided with $10 \mathrm{ml}$ of suspension. A set of six identical vessels was used in a thermostat $\left(30^{\circ} \mathrm{C}\right)$ and illuminated by six incandescent lamps. The highest light intensities obtainable were about $0.5 \mathrm{cal} / \mathrm{cm}^{2} \mathrm{~min}$. By using wire screens these intensities could be decreased as desired.

In several experiments a specific dose of some reagent had to be added to the suspension without disturbing the experiments. (Disturbance is hardly avoidable with the normal procedure of "tipping" from a side bulb). The arrangement used for this purpose is shown in Fig. 2. It consisted of a stopcock arrangement, the plug of which was provided with a cavity about $0.25 \mathrm{ml}$ in volume.

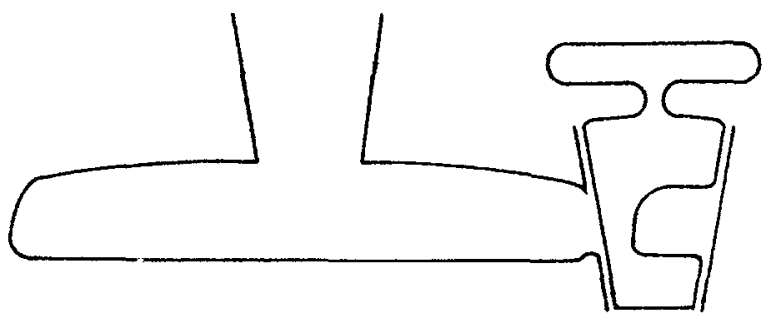

Fig. 2 Illustration of the vessel adapted to "Tipphg" experiments. 
Before starting the experiment this cavity had to be completely filled with the desired solution, after which the stopcock was closed and the vessel rinsed. At the desired moment during the experiment a $180^{\circ}$ turn of the stopcock caused a fast mixing of the two liquids. Re-equilibration after this manipulation was complete in less than a minute, and an additional advantage of the arrangement was that there could be no change of the position of the vessel in the optical path.

EXPERIMENTAL RESULTS

$\mathrm{O}_{2} / \mathrm{NH}_{4}$ ratio

$\mathrm{m} \mathrm{mol} \mathrm{O}_{2}$

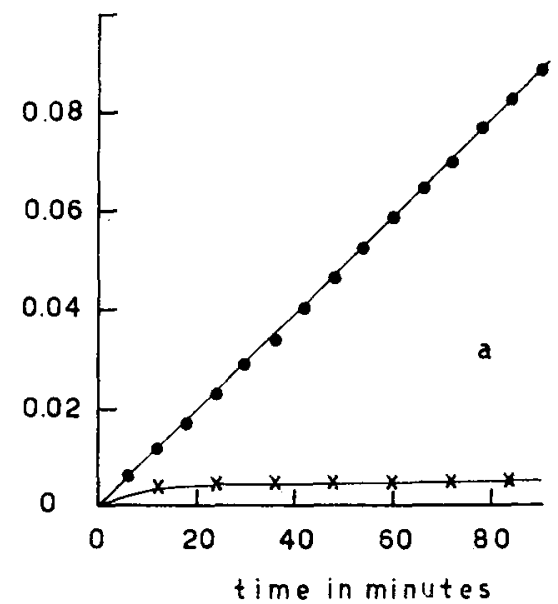

$\mathrm{mmol} \mathrm{O}_{2}$

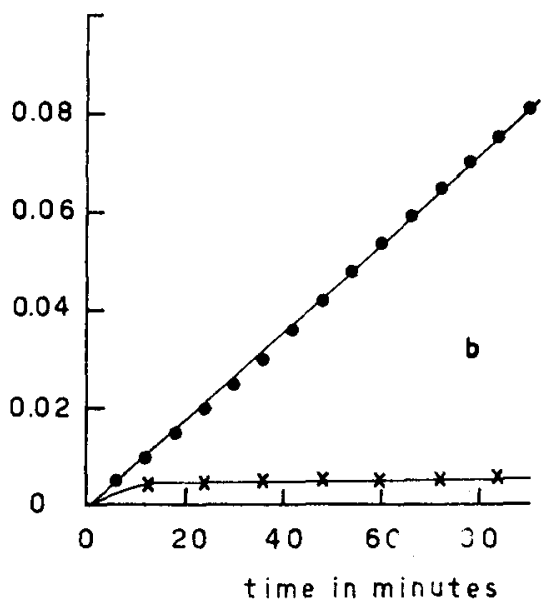

Fig. 3 Time COURSE OF OXYGEN Evolution IN LIGHT IN THE ABSENCE OF CO 2 IN MEDIA CONTAINING either $\mathrm{KNO}_{3}$ (a), oR $\mathrm{KNO}_{2}$ (b). Crosses indicate no adDition as conTROY. INITIAL CONCENTRATION $0.015 \mathrm{M}$ NITROGEN. Light INTENSITY $0.5 \mathrm{cal} / \mathrm{CM}^{2} \mathrm{MIN}$.

We observed that algae suspended in adequately buffered media, if exposed to light in the absence of $\mathrm{CO}_{2}$ and in the presence of $\mathrm{NO}_{3}{ }^{-}$or $\mathrm{NO}_{2}{ }^{-}$, produced oxygen at a fairly uniform rate for a considerable time (hours). Figs $3 a, b$ represent such experiments, and also show that oxygen evolution is negligible in a control suspension without a nitrogen and a carbon source. It was shown previously (1) that under such conditions the cells excrete ammonia in the medium at a uniform rate. A number of experiments were carried out to determine the ratio between the amount of oxygen evolved and the amount of ammonia excreted (the $\mathrm{O}_{2} / \mathrm{NH}_{4}$ quotient). The results are listed in Table 1 .

Table 1 Average $\mathrm{O}_{2} / \mathrm{NH}_{4}$ quotient observed under conditions of strong and weak light in the absence of $\mathrm{CO}_{2}$, in media containing nitrate, nitrite, or nitrate + nitrite. Suspensions buffered at pH 7.3 with a $(0.07$ mol.) tris-phosphate buffer.

\begin{tabular}{c|c|c|c|c}
\hline Series & $\begin{array}{c}\text { Number of } \\
\text { experiments }\end{array}$ & N-source & Weak light & Strong light \\
\hline $\mathrm{a}$ & 5 & $\mathrm{KNO}_{3}$ & $1.97 \pm 0.06$ & $1.93 \pm 0.04$ \\
$\mathrm{~b}$ & 14 & $\mathrm{KNO}_{3}$ & - & $1.47 \pm 0.03$ \\
$\mathrm{c}$ & 5 & $\mathrm{KNO}_{2}$ & $1.45 \pm 0.05$ & $1.53 \pm 0.09$ \\
$\mathrm{~d}$ & 14 & $\mathrm{KNO}_{2}$ & - & 1.53 \\
\hline
\end{tabular}


There are strong indications that two molecules of oxygen are produced in both weak and strong light (series $a$ and $b$ ) per molecule of nitrate reduced. Less oxygen is evolved per molecule of nitrite reduced (series $c$ and $d$ ). The $\mathrm{O}_{2} / \mathrm{NH}_{4}$ quotients in this case were close to 1.5. The observation that the quotient does not differ greatly from 1.5 when both nitrate and nitrite are available probably indicates that nitrite is reduced in preference to nitrate.

\section{Correlation between the rates of $\mathrm{CO}_{2}, \mathrm{NO}_{3}{ }^{-}$and $\mathrm{NO}_{2}{ }^{-}$reduction in light}

In a number of experiments we compared the rate of oxygen output as a function of light intensity in media containing $\mathrm{NO}_{3}{ }^{-}$or $\mathrm{NO}_{2}^{-}$in the presence or absence of $\mathrm{CO}_{2}$. Fig. 4 shows the rate of oxygen output in the absence of $\mathrm{CO}_{2}$ in two parallel samples of algae, one suspended in a nitratecontaining medium (cf. Fig. 4, curve 1), the other in a nitrite-containing medium (cf. Fig. 4, curve 2). The dotted lines in this figure represent the rates of ammonia excretion (curve $3:$ in the nitrate-containing medium, curve $4:$ in the nitrite-containing medium), as calculated with the $\mathrm{O}_{2} / \mathrm{NH}_{4}$ quotient discussed in the preceding section.

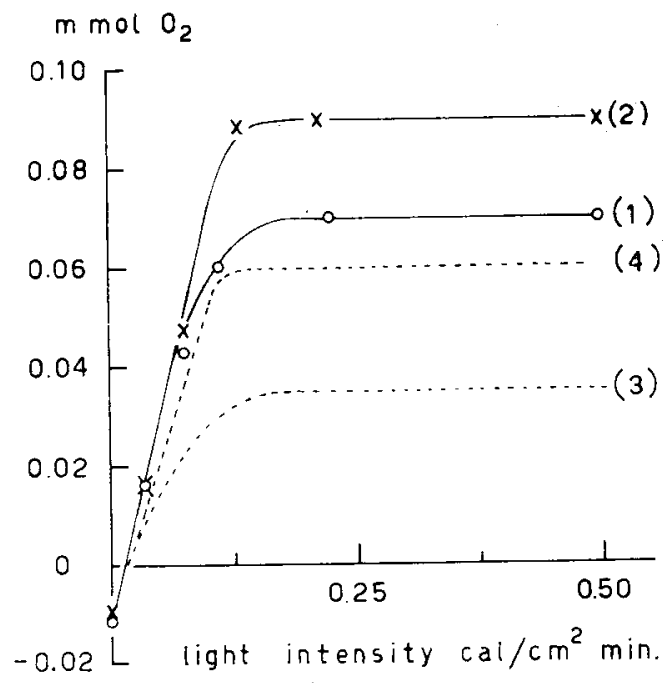

Fig. 4 RELATION BETWEEN RATE OF OXYGEN EVOLUTION AND LIGHT INTENSITY, MEASURED IN THE ABSENCE OF $\mathrm{CO}_{2}$, IN MEDIA WITH EITHER $\mathrm{KNO}_{3}$ (CURVE 1), OR $\mathrm{KNO}_{2}$ (CURVE 2). DOTTED CURVES REPRESENT THE RATE OF AMMONIA EXCRETION, CALCULATED ON BASIS OF $\mathrm{O}_{2} / \mathrm{NH}_{4}$ QUOTIENTS OF 2.0 IN THE $\mathrm{NO}_{3}{ }^{-}$CONTAINING MEDIUM (CURVE 3), AND 1.5 IN THE $\mathrm{KNO}_{2}$ MEDIUM (CURVE 4).

The rate of ammonia excretion in strong light is considerably higher in the nitrite-containing suspension than in the suspension supplied with nitrate. This phenomenon was also observed by KessLer (5) and will be discussed in a forthcoming paper.

Fig. 5 represents the oxygen output measured at various intensities with three parallel samples of algae suspended in media containing either $\mathrm{NO}_{3}{ }^{-}$ in the absence of $\mathrm{CO}_{2}$ (open circles), or $\mathrm{CO}_{2}$ in the absence of $\mathrm{NO}_{3}^{-}$(dots), or containing both $\mathrm{CO}_{2}$ and $\mathrm{NO}_{3}{ }^{-}$(triangles). Fig. 6 represents a similar experiment, in which, however, $\mathrm{NO}_{3}^{-}$was replaced by $\mathrm{NO}_{2}^{-}$. These figures 
show that in weak light a linear relation exists between oxygen output and light intensity, and that with higher light intensities all processes attain saturation showing that dark reactions limit the maximum rates.

For a given amount of weak light the same amount of oxygen is evolved, irrespective of the substrate or substrates reduced. Fig. 7 again illustrates that the oxygen production in the light-limiting range is independent of the nature of the oxidant.

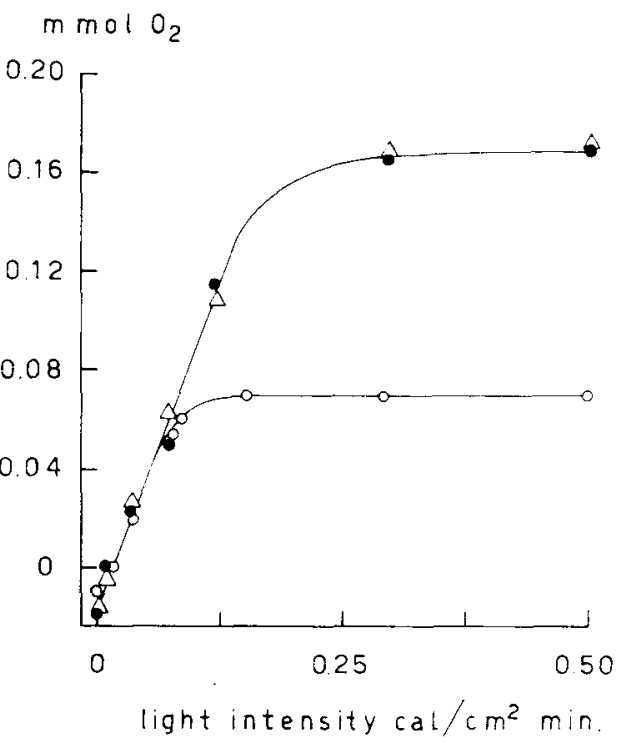

FIG. 5

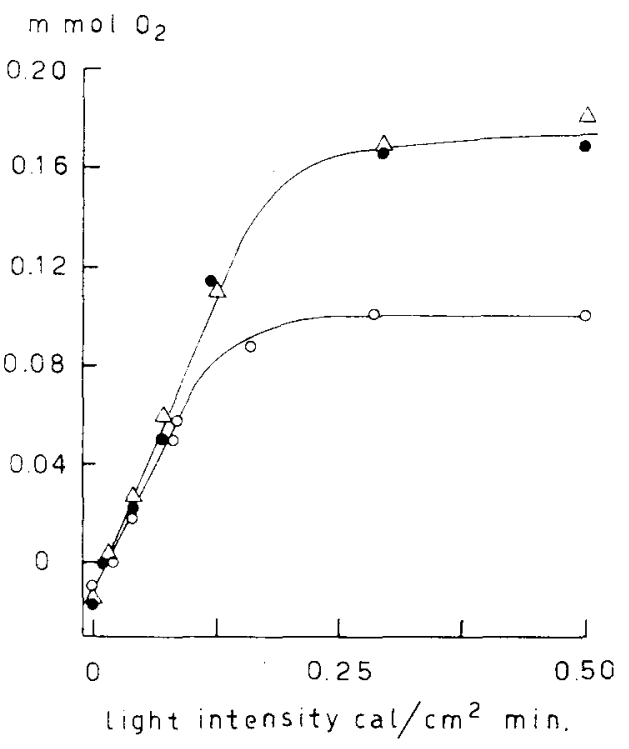

FIG. 6

Fig. 5 Relation Between Light INTENSITY aNd RATE OF OXYGEN EVolution IN MEDIa CONTAINING EITHER NITRATE IN THE ABSENCE OF $\mathrm{CO}_{2}$ (OPEN CIRCLES), OR $\mathrm{CO}_{2}$ IN THE absence of nitrate (Closed circles), or in the pResence of both $\mathrm{CO}_{2}$ and $\mathrm{NO}_{3}$ (TRIANGLES).

Fig. 6 Legend as Fig. 5. Nitrogen source $\mathrm{KNO}_{2}$.

We may conclude that the photosynthetic quantum yield $h_{\mu} / \mathrm{O}_{2}$ is the same for nitrate, nitrite and $\mathrm{CO}_{2}$ reduction. Since only $/ / 2$ molecule of $\mathrm{NO}_{3}{ }^{-}$is reduced and $2 / 3$ molecule of $\mathrm{NO}_{2}{ }^{-}$per $\mathrm{O}_{2}$ evolved the quantum requirement per $\mathrm{N}$ atom is considerably higher than that per $\mathrm{C}$ atom in carbon reduction.

In strong light both $\mathrm{CO}_{2}$ and $\mathrm{NO}_{3}{ }^{-}$or $\mathrm{NO}_{2}{ }^{-}$reduction attain saturation rates. The maximum level of oxygen evolution with $\mathrm{CO}_{2}, \mathrm{CO}_{2}+\mathrm{NO}_{3}{ }^{-}$ (cf. Fig. 5) and $\mathrm{CO}_{2}+\mathrm{NO}_{2}^{-}$(cf. Fig. 6) is higher than the maximum rate of oxygen evolution found with these nitrogen sources in the absence of $\mathrm{CO}_{2}$. This approximately twofold difference in oxygen evolution between the saturation rates of nitrate and $\mathrm{CO}_{2}$ reduction corresponds to the approximately fivefold difference between the saturation rate of oxygen output in a $\mathrm{CO}_{2}$ containing algal suspension and the ammonia excretion in a nitrate-containing suspension in the absence of $\mathrm{CO}_{2}$, as was described previously (1). It may be concluded from the present experiments that the same difference exists between the rates of nitrite and $\mathrm{CO}_{2}$ reduction.

A second point of interest is that the maximum rate of oxygen output in 


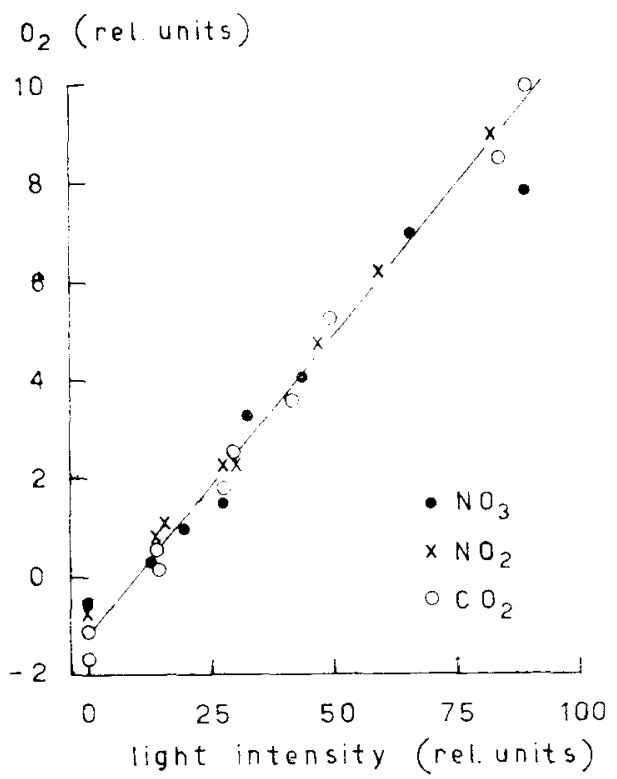

Fig. 7 Relation Between the Rate of OXYgen eVolution as a fUnction of light inteNSITY, IN MEDIA CONTAINING EITHER NITRATE (CLOSED CIRCLES), NITRITE (CROSSES) BOTH IN TRIS-PHOSPHATE BUFFER ( $\mathrm{pH} 8.4$ ), OR $\mathrm{CO}_{2}$ (OPEN CIRCLES) IN A 0.2 M CARBonate BUFFER ( $\mathrm{pH} 8.4)$.

$\mathrm{m} \mathrm{mol} \mathrm{m}_{2}$

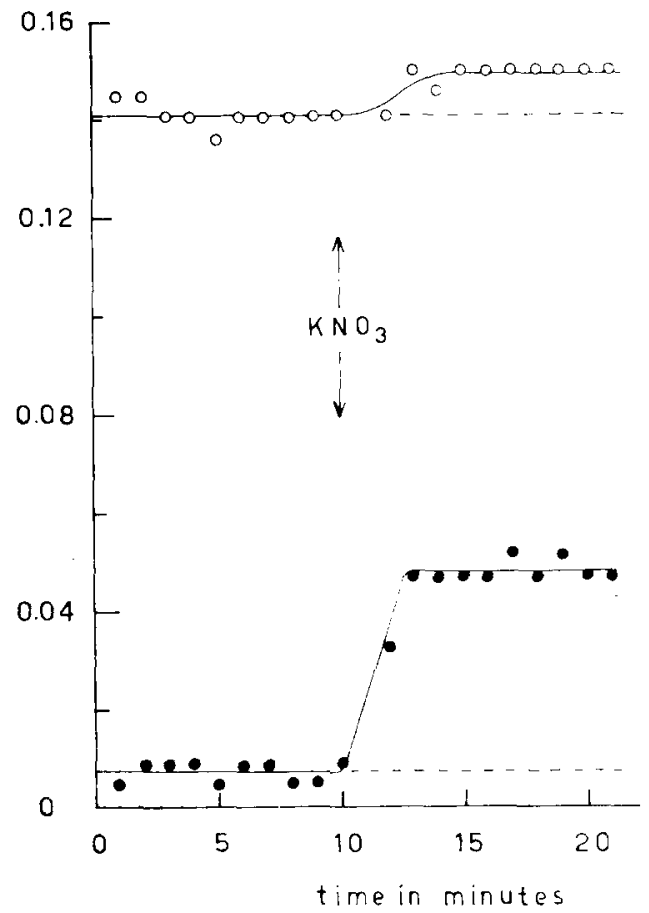

FIG. 8

$$
\mathrm{m} \mathrm{mol} \mathrm{O}_{2}
$$

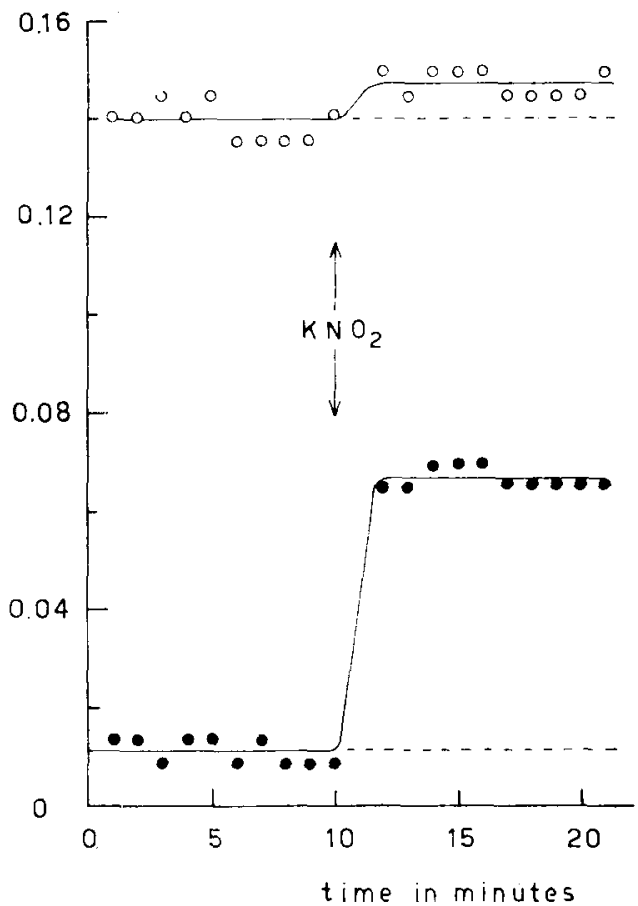

Fig. 9

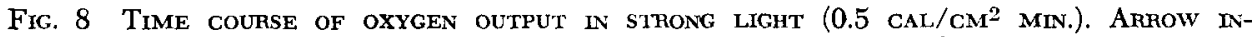
DICATING $\mathrm{KNO}_{3}$ ADDITION VIA THE STOPCOCK ARRANGEMENT. TOP : 0.2 MOLAR CARBONATE BUFFER ( $\mathrm{pH}$ 8.4). BELOW : 0.07 MOLAR TRIS-PHOSPHATE BUFFER ( $\mathrm{pH} 8.4$ ).

Fig. 9 Legend as Fig. 8. Nitrogen source $\mathrm{KNO}_{2}$. 


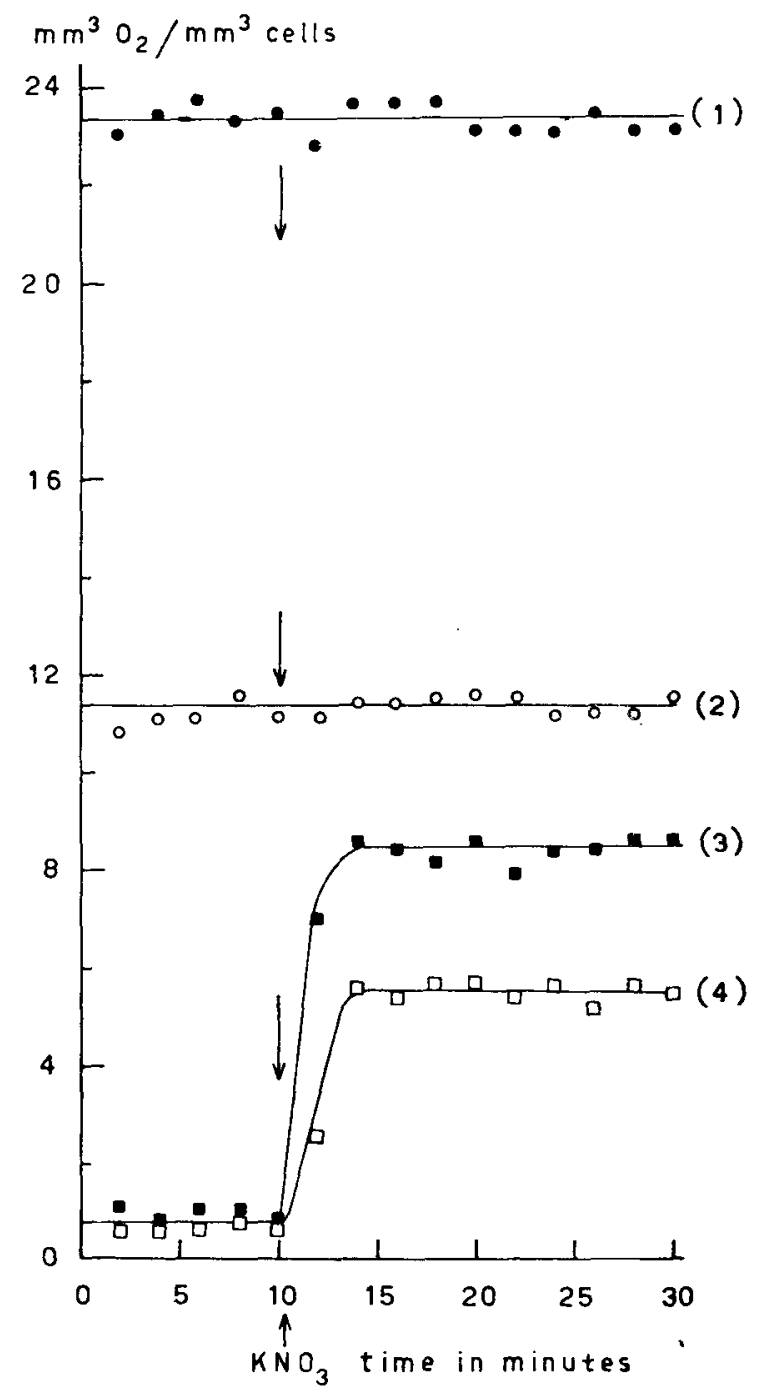

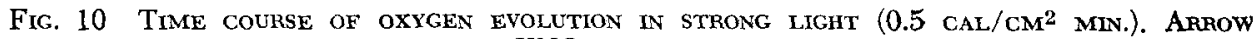
INDICATES THE ADDITION OF $\mathrm{KNO}_{3}$ VIA STOPCOCK ARRANGEMENT.

Normal cells : curve 1, $0.2 \mathrm{M}$ carbonate buffer ( $\mathrm{pH}$ 8.4); curve 3, 0.07 M tris-phosphate buffer ( $\mathrm{pH} 8.4$ ).

$\mathrm{N}$-starved cells : curve $2,0.2 \mathrm{M}$ carbonate buffer $(\mathrm{pH} 8.4)$; curve 4, 0.07 M tris-phosphate buffer (pH 8.4).

a carbon dioxide-containing suspension is hardly if at all influenced by the presence or absence of nitrate or nitrite. The saturation rates are equal within experimental error, independent of a possible $\mathrm{NO}_{3}{ }^{-}$or $\mathrm{NO}_{2}{ }^{-}$reduction in addition to $\mathrm{CO}_{2}$ reduction. These observations were confirmed by a number of "tipping" experiments. In these experiments, shown in Figs 8 and 9 , the oxygen evolution was measured versus time in a $0.2 \mathrm{M}$ carbonate buffer in saturating light. At a given moment (indicated by arrows) nitrate or nitrite was introduced with the stopcock arrangement shown in Fig. 2. This method enabled us to measure more accurately a possible increase of oxygen evolution 
due to the onset of nitrate reduction. With a parallel sample of algae, and with the same technique, the oxygen evolution was measured before and after the addition of nitrate or nitrite in the absence of $\mathrm{CO}_{2}$. These experiments show that in the absence of $\mathrm{CO}_{2}$ a rapid increase of oxygen evolution occurs upon the addition of $\mathrm{NO}_{3}{ }^{-}$or $\mathrm{NO}_{2}{ }^{-}$. But in the presence of $\mathrm{CO}_{2}$ this increase is very limited, amounting to some $5 \%$ or less of the prevailing rate.

We also measured the enhancing effect of nitrate on photosynthetic oxygen evolution with cell material of a decreased photosynthetic activity. The algal cells were exposed to strong light for 3 hours in nitrogen-deficient media (1). As may be seen in the experiment illustrated in Fig. 10, (came out in a similar way to those of Figs. 8 and 9), no increased rate of oxygen evolution could be observed after addition of nitrate, although the saturation rates of $\mathrm{CO}_{2}$ reduction differed by a factor two.

\section{Discussion}

Quantitative relationships between oxygen evolution and nitrate or nitrite reduction have been observed by many workers. Davis (7) found an "extra" $\mathrm{O}_{2}$ output in light as a consequence of nitrate reduction in glucose-containing algal suspensions, and it can be concluded from his results that two molecules of oxygen are evolved for each molecule of nitrate. Syretr $(8,9)$ using nitrogenstarved Chlorella cells, observed that in the reduction of nitrate and nitrite in darkness about 2.0 respectively 1.5 molecules of "extra" $\mathrm{CO}_{2}$ were evolved per molecule of reduced substrate. KEssLER (5) demonstrated a reduction of nitrite in light by Ankistrodesmus and observed a quotient $\left(\mathrm{O}_{2} / \mathrm{NO}_{2}\right)$ of 1.5 . A similar relationship was also found by VANECKo et al. (10) with wheat leaves. With hydrogenase containing algae (Ankistrodesmus braunii and Scenedesmus obliques " $\mathrm{D}_{3}$ "), incubated under an atmosphere of hydrogen in darkness, KESSLER (11) recorded a rapid uptake of hydrogen upon addition of nitrite. He interprets his experimental results by the following equation: $\mathrm{HNO}_{2}+3 \mathrm{H}_{2} \longrightarrow$ $\mathrm{NH}_{3}+2 \mathrm{H}_{2} \mathrm{O}$. This was in good agreement with the earlier observation of Woops (12) with Clostridium welchii, who observed a consumption of 4 molecules of hydrogen per molecule of nitrate and 3 molecules of hydrogen per molecule of nitrite reduced.

The experimental results all clearly indicate that the following general stoichiometric equation may be written for nitrate and nitrite reduction:

$$
\begin{aligned}
& \mathrm{HNO}_{3}+8 \mathrm{H} \underset{\text { and }}{\longrightarrow} \mathrm{NH}_{3}+3 \mathrm{H}_{2} \mathrm{O} \\
& \mathrm{HNO}_{2}+6 \mathrm{H} \longrightarrow \mathrm{NH}_{3}+2 \mathrm{H}_{2} \mathrm{O}
\end{aligned}
$$

In darkness the hydrogen will be generated by oxidation of added or previously formed reduced chemical substances. In light the reducing capacity will be ultimately generated by the photolysis of water.

In the endothermic conversion of 1 mole of $\mathrm{CO}_{2}$ to carbohydrate, expressed as $\left(\mathrm{CH}_{2} \mathrm{O}\right), 112 \mathrm{kcal}$ are fixed. The conversion of nitrate and nitrite to ammonia involves energy fixations of about 73 and $54 \mathrm{kcal}$ per mole respectively. Since per mole $\mathrm{O}_{2}$ evolved in the reduction of nitrate and nitrite about 36 kcal are stored (73 kcal per mole $\mathrm{NO}_{3}{ }^{-}$and $54 \mathrm{kcal}$ per mole $\mathrm{NO}_{2}{ }^{-}$) the energetic efficiency of these processes is quite low compared to the efficiency of the photosynthetic $\mathrm{CO}_{2}$ reduction (about $33 \%$ ). 
The above-mentioned observations fit in the general pattern of quantum conversion in photosynthesis such as was observed with chloroplast reactions and purple sulphur bacteria. They appear to confirm the generalisation that the quantum requirement of a process is stoichiometrically related to the number of hydrogen transfers, and not to the energy relations.

In our experiments we did not confirm the results of VAN NIEL and Coworkers (6) who report that Chlorella suspensions at high light intensities, supplied with non-limiting $\mathrm{CO}_{2}$ concentrations, produce oxygen at a greater rate when nitrate is simultaneously present. In their experiments the increasing effect of nitrate yielded results varying from $9 \%$ to $60 \%$ of the amount of oxygen produced in the absence of nitrate. This increase is related to the photochemical reduction of nitrate. Their findings led them to the conclusion that in the presence of both nitrate and $\mathrm{CO}_{2}$ an additional hydrogen acceptor (nitrate reducing system) is in operation, resulting in an additional amount of oxygen. In the absence of $\mathrm{CO}$.2 we found a substantial rate of oxygen output in nitrate- and nitrite-containing algal suspensions, viz. from $40 \%$ to $50 \%$ of the rate of oxygen output found in the presence of $\mathrm{CO}_{2}$ only; in the presence of both $\mathrm{CO}_{2}$ and nitrate, however, the rate of oxygen output was only slightly increased, viz. from $0 \%$ to about $8 \%$ of the rate found in the presence of $\mathrm{CO}_{2}$.

The said discrepancy can be understood by considering the location of the limiting factor in the photochemical $\mathrm{CO}_{2}$ reduction. According to VAN NIEL's opinion, at high light intensities the rate of photosynthesis is limited by the concentration of the hydrogen acceptor ( $\mathrm{CO}_{2}$ or phosphoglyceric acid). If the supply of hydrogen-enzyme-complex is more than can be handled by the hydrogen acceptor mentioned, the excess reductants could be utilized by the enzymes involved in nitrate reduction, yielding an additional amount of oxygen. In our experiments such an additional amount of oxygen was not recorded. Consequently we are inclined to conclude that under conditions of strong light, even far beyond "light saturation", the supply of photosynthetic reductant does not exceed the amount which can be handled by the enzymes involved in the reduction of CO.. This implies an earlier location in the chain of photosynthetic dark reactions of the rate-limiting factor than suggested by VAN NIEL et al., a fact supported by kinetic studies of photo-inhibition and photosynthesis in flashing light (cf. KoK (13)).

\section{REFERENCES}

Bongers, L. H. J. : Thesis Wageningen (1956).

Myers, J. and L. B. Clakk : J. Gen. Physiol. 28 (194t) 103.

3 Tamrya, H., T. Iwamura, K. Shibati, E. H.se and T. Ninei : Bioch. et Bioph. Acta 12 (1953) 23.

4 SNELL, F. D. and C. T. SNeLL : Colorimetric methods of analysis. London, vol. II (1949) 802.

Kessler, E. : Nature 176 (1955) 1069.

Niel, C. B. van, M. B. Altan and B. E. Wrigirt : Bioch. et Bioph. Acta 12 (1953) 67.

Davis, E. A. : Plant Physiol. 28 (1953) 539.

Syrett, P. J.: Physiol. Plant 8 (1955) 924.

- - : Physiol. Plant 9 (1956) 28.

10 Vanecko, S. and J. E. Varner: Plant Physiol. 30 (1955) 388.

11 Kessler, E. : Archives of Bioch. and Bioph. 62 (1956) 241.

12 Woons, D. D. : Bioch. J. 32 (1938) 2000.

13 Koк, B. : Bioch. et Bioph. Acta 21 (1956) 245. 